\title{
ОГЛЯД СУЧАСНИХ ПІДХОДІВ ДО РОЗРОБКИ НАНОЛІКІВ
}

\author{
Брубейкер I. O., \\ к.фарм.н., доцент, Кафедра фармацевтичного менеджменту, клінічної фармацій, технологї̈ \\ ліків, ПВНЗ «Київський медичний університет», Київ, Украӥна \\ ORCID ID: https://orcid.org/0000-0002-0049-9513
}

Білан О. А., стариий викладач, Кафедра фармачевтичного менеджменту, клінічної фармачії, технології ліків, ПВНЗ «Київський медичний університет», Київ, Украӥна ORCID ID: https://orcid.org/0000-0002-2720-6864

\begin{abstract}
Марченко-Толста К. С., асистент, Кафедра фармакологї, клінічної фармакології, патофізіологї ПВНЗ «Київський медичний університет», Київ, Украӥна ORCID ID: https://orcid.org/0000-0001-7744-5874
\end{abstract}

DOI: https://doi.org/10.31435/rsglobal_ws/31052020/7081

\section{ARTICLE INFO}

Received: 29 March 2020

Accepted: 20 May 2020

Published: 31 May 2020

\section{KEYWORDS}

nanomedicine, nanotechnology, nanopharmacy, nanodrugs, nanoparticles.

\begin{abstract}
The article deals with nanopharmacy, a new medical discipline that combines chemistry, physics and engineering to develop nanoscale systems used in diagnosis and therapy. The use of nanoparticles for the development of new nanodrugs requires a deep understanding not only of the properties of nanomaterials, but also of the pathophysiology of diseases. Nanopharmacy help solve complex problems associated with improving the effectiveness of existing therapeutic agents and the use of nanomaterials in the manufacture of nanodrugs.
\end{abstract}

Citation: Brubaker I. O., Bilan O. A., Marchenko-Tolsta K. S. (2020) Review of Modern Approaches to the Development of Nanodrugs. World Science. 5(57), Vol.2. doi: 10.31435/rsglobal_ws/31052020/7081

Copyright: (C) 2020 Brubaker I. O., Bilan O. A., Marchenko-Tolsta K. S. This is an open-access article distributed under the terms of the Creative Commons Attribution License (CC BY). The use, distribution or reproduction in other forums is permitted, provided the original author(s) or licensor are credited and that the original publication in this journal is cited, in accordance with accepted academic practice. No use, distribution or reproduction is permitted which does not comply with these terms.

Вступ. Напрямок сучасних технологій, що працюють із дослідженням, виробництвом і застосуванням матеріалів і приладів у масштабі від 1 до 100 нм (нанометр - одна мільярдна частина метру, $1 \times 10^{-9}$ м) принаймні в одному вимірі, називають «нанотех». Європейська Комісія визначає нанотехнології як одну 3 шести «ключових допоміжних технологій» (key enabling technologies), що сприяють стабільній конкурентоспроможності та зростанню в декількох галузях промисловості [2].

Останнім часом ця сфера дуже швидко розвивається. Наприклад, одна 3 найвідоміший баз наукових праць PubMed на запит «nanopharmacology review» пропонує 1765 матеріалів, а Швейцарський науково-дослідний фонд Geneva Foundation for Medical Education and Research (GFMER) у англомовному розділі «наномедицина, нанотехнології» своєї бази безкоштовних медичних видань містить 59 журналів [7].

Хоча, дехто з дослідників вважає, що «не існує наномедицини, $є$ нанотехнології в медицині - медицина, заснована на нанотехнологіях» [1], на сьогодні виділяють наступні напрямки:

- «Наномедицина» (nanomedicine, nanomedical technologies) - застосування нанотехнологій у медичних дослідженнях і клінічній практиці для діагностики, лікування та профілактики хвороб, моніторингу та контролю біологічних систем, регенерації тканин і органів, а також для отримання більш глибокого уявлення про патофізіологію, що лежить в основі захворювання. 
- «Нанофармакологія» (nanopharmacology) - вивчення взаємодії між біомолекулами, штучними молекулярними збірками та нанопристроями всередині клітин і у позаклітинному середовищі, а також механізмів дії, біологічних ефектів та фармакокінетики наноліків.

- «Фармацевтичні нанотехнолохії» (pharmaceutical nanotechnology) або «нанофармація» (nanopharmaceuticals, nanopharmacy) - розробка нових ліків, а також фармацевтичних, терапевтичних і діагностичних засобів та методів їх націлювання, раціональної доставки та контролю вивільнення. Отже, основною метою нанофармації $є$ використання нанонауки для створення нових препаратів з підвищеною терапевтичною ефективністю [5].

Мета дослідження. Метою роботи є дослідження сучасних тенденцій розвитку нанотехнологій у фармації в такому напрямку, як розробка наноліків.

Методи дослідження. Аналіз літератури (першоджерел), порівняльний аналіз різних методичних підходів, контент-аналіз текстів.

Результати дослідження. Відокремлення нанотехнологій обумовлено тим, що властивості матеріалів на атомному та молекулярному рівнях суттєво відрізняються від тих, що спостерігаються в макромасштабі. Через високу питому поверхню наноматеріалів (відношення площі поверхні до об'єму) велику роль починають грати поверхневі явища - адсорбціядесорбція та адгезія, а також квантові ефекти. Наприклад:

- композити з наночасток (НЧ) кераміки або металів з розміром зерна близько 10 нм в 7 разів твердіше і міцніше, ніж їх аналоги «звичайного» масштабу;

- НЧ здатні розчинятися у воді більш ефективно, ніж існуючі, підвищуючи активність препаратів, які їх містять;

- керований процес усадки пір у нанопористих матеріалах забезпечує контроль властивостей поверхні на місці дії речовини;

- вуглецеві нанотрубчасті структури, що містять нанометричні та субнанометрічні гідрофільні пори, мають високу іонну селективність та забезпечують швидке перенесення речовин;

- гідрофільні пори, що самозбираються, можуть утворювати трансмембранні канали 3 дуже великою іонною провідністю. І т. д.

На сьогодні у нанофармації використовують 2 типа НЧ: органічні (полімерні міцели, кон'югати полімерних ліків, дендримери, нанокристали, ліпосоми) і неорганічні (металеві золото, срібло, залізо, платина, квантові точки, та кремнеземні - мезопористі, ксерогелі). Нерідко поверхня НЧ розробляється з використанням лігандів для отримання спорідненості до специфічних клітин і кополімерів для отримання захисту від імунних клітин.

Ще одна класифікація поділяє наноматеріали на такі групи:

1) НЧ, що діють як біологічні міметики (наприклад, функціоналізовані вуглецеві нанотрубки);

2) «наномашини» (наприклад, зроблені з взаємозамінних частин ДНК і каркасів ДНК);

3) біоматеріали 3 нановолокон, нанокомпозитів/нанобіокомпозитів, полімерних наноструктур (наприклад, молекулярні самозборки, нановолокна пептидів і пептид-амфіфіли для тканинної інженерії, полімери з пам'яттю форми як молекулярні перемикачі, нанопористі мембрани), ліпідів (ліпосоми, нанобульбашки - nanobubbles) і т. п.;

4) нанорозмірні пристрої (наприклад, кремнієві мікрочіпи для вивільнення лікарських засобів, нанопроцессори, нанорідинні транзистори і т. д.);

5) наносенсори для лабораторної діагностики і т. ін.

Найчастіше синтетичні або природні НЧ застосовуються для розробки нових фармацевтичних препаратів - «наноліків» (nanodrugs, nanomedicines, drug loaded nanoformulations). Нанофармацевтічним називають препарат, в якому наноматериал відіграє основну терапевтичну роль, додає нові функціональні можливості або підвищує ефективність традиційних лікарських засобів. Зазвичай наноліки складаються з біосумісних або таких, що біорозкладаються, колоїдних частинок субмикронного розміру, інкапсулюючих діючу речовину. Властивості НЧ:

- убезпечують унікальні характеристики фармацевтичної форми (дендримери, нанокристали, емульсії, гелі, ліпосоми, полімерні біорозкладні нанокапсули, мікросфери, нанотрубки, дисперсії, еластомери, коллідосоми, фамакосоми, аквасоми, етносоми, суспензії, поліплекси та ліпополіплекси, полімерні міцели і т. д. - див. Рис. 1), а також

- суттєво впливають на фармакокінетичні/фармакодинамічні профілі фармацевтичних інгредієнтів та фармакокінетику ліків (всмоктування, розподіл в тканинах-мішенях, метаболізм, біотрансформація та екскреція), через що навіть мізерні концентрації речовини можуть суттєво впливати на функціонування організму. 


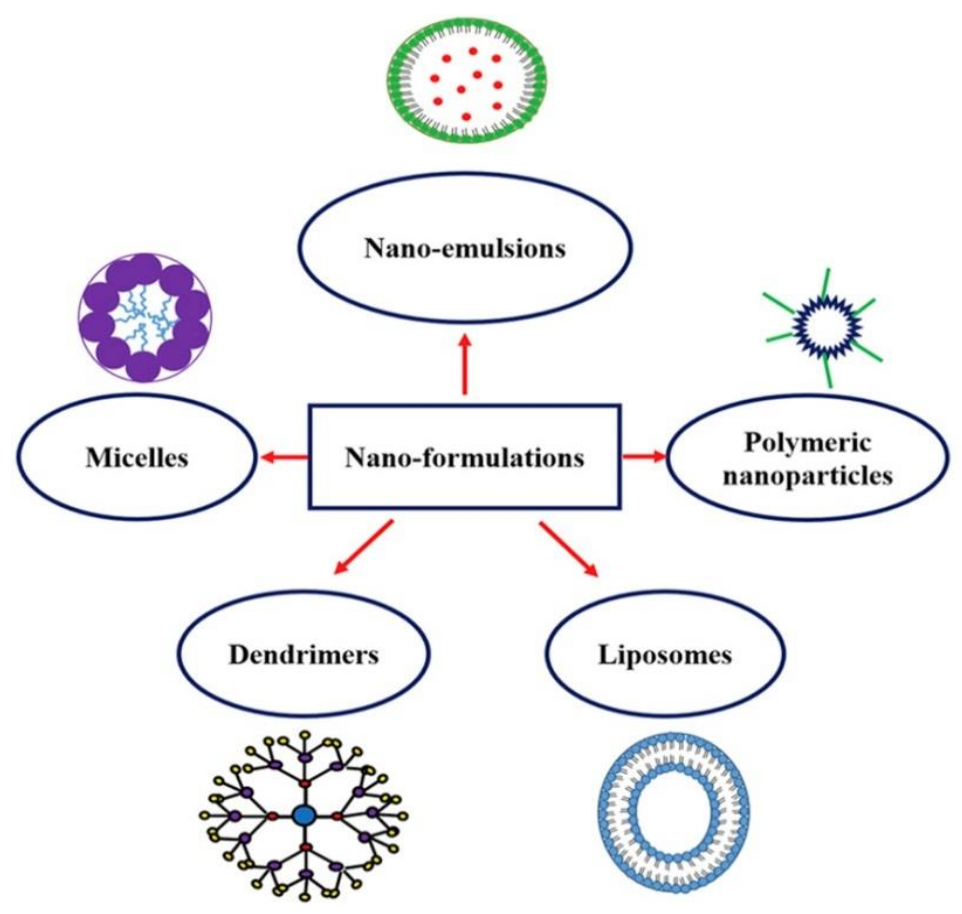

Рис. 1. Фармацевтичні форми [4]

Серед наноматеріалів особливу увагу привертають дендримери -полімерні наноархітектури, що характеризуються гіперрозгалуженою чітко визначеною 3D-структурою у формі зірки. Безліч функціональних груп на поверхні підвищує їх функціональність та забезпечує універсальність і біосумісність, а унікальні властивості (рівномірні розміри, висока ступінь розгалуженості, полівалентність, водорозчинність, майже монодисперсність, доступні внутрішні порожнини і зручні підходи до синтезу) роблять перспективним засобом конструювання нових ліків. Дендримери можуть бути синтезовані практично з будь-якої основної молекули та гілок, також сконструйованих з будь-якої біофункціональної молекули. Наноносії на основі дендримерів (включаючи кон'югати дендримерів, дендримери Януса та лінійно-дендритні блок-сополімери) можуть доставляти широкий спектр терапевтичних засобів, такі як малі молекули, пептиди і гени, знижуючи за рахунок точного наведення системну токсичність і підвищуючи ефективність. Молекули діючої речовини можуть бути завантаженні всередину дендримерів, або приєднані до поверхневих груп.

Синтез НЧ для застосування у фармацевтиці може йти «від низу до верху» (піроліз, конденсація інертного газу, сольватермічна реакція, золь-гелеве виготовлення, використання ліпосом в якості основи для кріплення лікарського засобу та ін.) i «зверху вниз» (стирання/подрібнення лікарської речовини до утворення НЧ, електророзпорошення та ін.). Полімерні НЧ виготовляються з використанням різних методів синтезу: нанопреціпітація, випаровування емульсіі/розчинника, емульгування, багаторазова емульсіфікація, електророзпорошення, десольватація, комплексоутворення поліелектролітів і т. п. [6]. Нові нанопрепарати розробляються також шляхом зміни різних функцій в їх хімічній структурі (розгалуження, стереохімія, гідрофобність, заряд).

Традиційні терапевтичні стратегії вимагають невиправдано високого системного введення ліків через неспецифічність їх біодинамічного розподілу та швидкий метаболізм (гідролітична та ферментативна деградація). У звичайних пероральних дозах ліки часто руйнуються при кишковому транзиті або погано всмоктуються і тому стають неефективними, до того ж неконтрольоване вивільнення терапевтичного агента викликає скачки його концентрації, що завдає шкоди організму в цілому. Прикріплення терапевтичних агентів до НЧ вирішує більшість 3 цих проблем. Серед переваг наноліків також:

- більш ефективний транспорт через кровоносні капіляри та лімфатичний ендотелій;

- можливість досягати більш високих концентрацій у тканинах-мішенях;

- висока стабільність та тривала циркуляція в крові;

- більш висока здатність до зв'язування з біомолекулами (ендогенними сполуками, включаючи білки); 
- контрольоване і стале вивільнення;

- вибірковість, специфічне націлювання та прицільна доставка діючої речовини;

- безпека: зниження окислювального стресу в тканинах, зменшення запальних/імунних реакцій (оскільки НЧ не ідентифікуються імунною системою) та токсичних побічних ефектів.

Фармакокінетичні характеристики наноліків визначаються розміром, формою (хімічною структурою) і хімічними характеристиками поверхні НЧ. Наприклад, комплекси з НЧ розміром менше 10 нм видаляються нирками, а більше 10 нм - печінкою i/або системою мононуклеарних фагоцитів. В цілому реакція на нанопрепарат залежить від здатності біоактивних НЧ (bioactive NPs) зв'язуватися з сайтом зв'язування ліганда рецептора на клітинній поверхні, тому основна мета дизайну нанорозмірних ліків (nano sized drugs) - передбачити, чи буде дана НЧ зв'язуватися 3 мішенню. Для прогнозування структури наноліків і моделювання змін в біологічних мішенях, які відбуваються, коли 3 ними зв'язуються НЧ, використовується молекулярна механіка/динаміка. Найчастіше такі фармацевтичні рецептури складаються з колоїдних часток субмікронного розміру, інкапсулюючих діючий препарат, але активно використовуються також функціоналізовані та модифіковані структури металевих, композитних, керамічних та полімерних наноматеріалів. Наприклад, гібридні ліпід-полімерні НЧ відзначаються високим ступенем інкапсуляції лікарських засобів, здатним до налаштування; стійким профілем вивільнення ліків; сироватковою стабільністю; потенціалом для диференційованого таргетування клітин або тканин. Такі структури складаються з різних функціональних компонентів: засоби;

1) гідрофобне полімерне ядро, в якому інкапсульовані погано розчинні у воді лікарські

2) гідрофільна полімерна оболонка 3 антібіообрастаючимі властивостями для підвищення стабільності НЧ і збільшення періоду напіврозпаду при системній циркуляції;

3) ліпідний моношар на стику ядра і оболонки, котрий діє як молекулярний паркан для утримання лікарського засобу всередині полімерного ядра.

Багатошарова структура підвищує ефективність інкапсуляції, збільшує завантаження лікарськими засобами та дозволяе контролювати їх вивільнення. Гідрофільні лікарські засоби можуть бути інкапсульовані у внутрішню порожнину з водою, а гідрофобні або амфіфільні введені всередину біслойних шарів (див. Рис. 2).

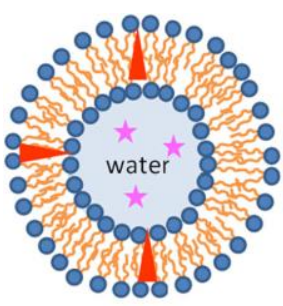

Liposome

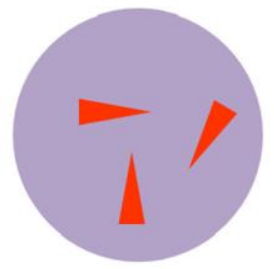

Nanosphere

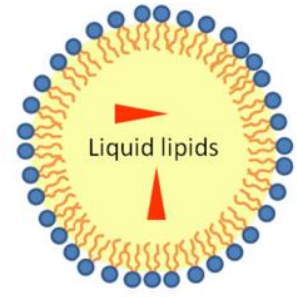

Nanoemulsion

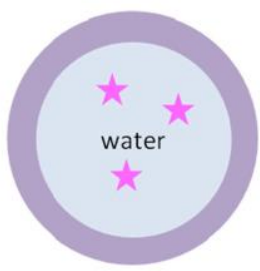

Nanocapsule (aqueous core)

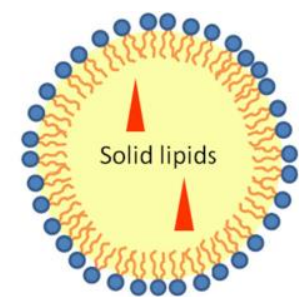

Solid Lipid Nanoparticle (SLN)

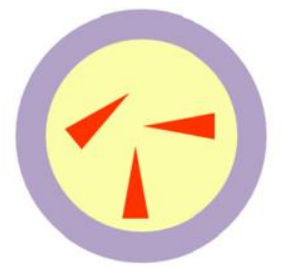

Nanocapsule (oily core)

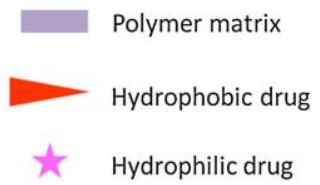

Рис. 2. Схеми наноліків, виготовлених на основі ліпідів (зверху), або полімерів (знизу) [3]

Складні наноструктури можуть бути сконструйовані за допомогою різноманітних методик, 3 використанням різних блоків (біосумісних або тих, що біорозкладаються), які поєднують такі функції, як націлювання, виявлення, терапія, контроль вивільнення, візуалізація та ін. Такий підхід дозоляє швидше розробляти нові ліки 3 широким терапевтичним діапазоном та/або поліпшеними фармакокінетичними властивостями in vivo. Для з'єднання біомакромолекул з наноматеріалами використовується кілька ковалентних шляхів кон'югації, в тому числі карбодіїміди, «клік»-опосередковані реакції, тіол-опосередковане кон'югування, біотин-авідінові взаємодії. 
Останнім часом все більше уваги дослідників привертають терапевтичні наноносії, що імітують природні компоненти біологічної системи та/або засновані на природних НЧ i біоматеріалах. Біологічно отримані наноносії демонструють кращу здатність переносити ліки до тканин, ніж «штучні», а також мають ще декілька переваг: висока біосумісність, здатність біологічно розкладатися, можливість націлювання та внутріклітинної доставки терапевтичного навантаження (наприклад, до тромбоцитів або клітинних органел). Особливо цікавим є напрямок, «натхненний» мікробами - терапевтична доставка вірусів.

Висновки. Використання у фармації нанотехнологій допомагає:

- удосконалювати вже існуючі ліки, в тому числі ті, що поки не можуть пройти клінічні випробування;

- більш раціонально (швидше та дешевше) досліджувати та виготовляти нові препарати;

- розробляти нові методи лікування - такі, як, наприклад, генна терапія (внутрішньоклітинна доставка нуклеїнових кислот);

- конструювати інтелектуальні багатофункціональні наноліки (smart multifunctional nanodrugs), які дозволяють точно націлювати терапевтичні агенти та керувати їх вивільненням за рахунок НЧ, чутливих до мікрооточення ( $\mathrm{pH}$, ферменти) або зовнішніх подразників (температура, світло, магнітні поля).

Серед головних переваг наноліків також треба відмітити персоналізований підхід до терапії на основі даних ex vivo та in vivo щодо стану пацієнта та перебігу захворювання, а також можливість розробляти «точні» (precision) ліки для персоналізованої терапії. У поєднанні 3 дослідженнями у фармакогеноміці, протеоміці та метаболоміці це дозволяє розробляти специфічне для кожного пацієнта лікування з урахуванням його генотипу та фенотипу, а також факторів навколишнього середовища, які можуть впливати на ефективність і безпеку терапії. Тому майбутнє - за індивідуалізованою медициною, де буде неприйнятно розробляти ліки, ефективні тільки для певного відсотку пацієнтів, де препарати будуть пристосовані до особливостей конкретної людини, де лікарі відмовляться від загальних терапевтичних схем і протоколів на користь специфічних для даного пацієнта методів лікування.

\section{ЛIТЕРАТУРА}

1. Boisseau P., Loubaton B. Nanoscience and nanotechnologies: hopes and concerns Nanomedicine, nanotechnology in medicine. C. R. Physique. 2011: 620-636

2. EC, Communication from the Commission to the European Parliament, the Council, the European Economic and Social Committee and the Committee of the Regions. 'A European strategy for Key Enabling Technologies - A bridge to growth and jobs'. Retrieved from http://eurlex.europa.eu/LexUriServ/LexUriServ.do?uri=COM: 2012:0341:FIN:EN:PDF (2012).

3. Fattal E., Tsapis N. Nanomedicine technology: current achievements and new trends. Clin Transl Imaging (2014) 2:77-87. DOI 10.1007/s40336-014-0053-3

4. Jeevanandam J., Chan Y.S., Danquah M.K. Nano-formulations of drugs: Recent developments, impact and challenges. Biochimie. 2016 Sep-Oct;128-129:99-112. doi: 10.1016/j.biochi.2016.07.008.

5. Hadjidemetriou M., Al-Ahmady Z., Mazza M., Kostarelos K. The Emergence of Nanopharmacy: From Biology to Nanotechnology and Drug Molecules to Nanodrugs (In book: Pharmaceutical Nanotechnology: Innovation and Production). 2016, pp.43-62. DOI: 10.1002/9783527800681.ch3

6. Moritz M., Geszke-Moritz M. Recent Developments in the Application of Polymeric Nanoparticles as Drug Carriers. Adv Clin Exp Med 2015, 24, 5, 749-758. DOI: 10.17219/acem/31802

7. Електронний pecypc: www.gfmer.ch/Medical_journals/Nanomedicine.htm. 